\title{
THE INFLUENCE OF REGIONAL SCIENCE UPON AGRICULTURAL ECONOMICS
}

James Hite*

\section{INTRODUCTION}

Like regional science, agricultural economics is a hybrid field of scholarship-not so much a discipline as a multidisciplinary subject matter area. Like regional science, agricultural economics borrows heavily from economics and is always in danger of being pulled into the disciplinary orbit of economics. Both fields are pragmatic in their approaches, and both place a high value on empirical analysis. These common features suggest that there are strong possibilities for fruitful interaction between regional science and agricultural economics.

Such interaction has occurred but has been limited because agricultural economics, at least in the United States, has evolved as agricultural rather than rural economics. That is, the principal focus of agricultural economics is upon a sector of the economy rather than upon the way that rural people make a living. Specialized scholarship focused upon rural economies/rural development is confined to only about 20 percent of the agricultural economics profession. Perhaps more than half of the agricultural economists who are involved with rural development are affiliated with a regional science organization and have been influenced in significant ways by regional science. Even so, they represent only about 10 percent of the agricultural economics profession and beyond their number, regional science has had almost no impact on agricultural economics.

The purpose of this paper is to explore the influence of regional science upon agricultural economics and (to a lesser degree) to determine the influence of agricultural economics upon regional science. To begin the exploration, I will outline the evolution of agricultural economics in the United States and attempt to provide some profile of the contemporary agricultural economics profession. I will then focus upon that involvement of the minority of agricultural economists who have become involved in organized regional science and who publish in the regional science journals and attempt to describe who they are and why they have found a "home away from home" in regional science. Finally, I will explore in a very cursory way some of the cross-fertilization between agricultural economics and regional science scholarship and speculate on future developments involving interactions between agricultural economics and regional science.

*The Strom Thurmond Institute, Clemson University, Clemson, South Carolina. 


\section{THE EVOLUTION OF AGRICULTURAL ECONOMICS}

Contrary to the assumption of most nonagricultural economists (and perhaps even of many agricultural economists), the intellectual genealogy does not begin in general economics. Some of the pioneers of scientific economics in the United States, most notably Richard Ely and John R. Commons, had a strong interest in the problems of agriculture, and there was discussion of agricultural problems at early meetings of the American Economic Association (Taylor 1952, 32-49). But the development of agricultural economics as a distinct field owes more to agricultural scientists like G. E. Morrow at (what is now) the University of Illinois; Thomas F. Hunt at Ohio State and, later, Cornell; Thomas C. Atkeson at West Virginia; Liberty Hyde Bailey at Comell; and William J. Spillman at the U.S. Department of Agriculture (Taylor 1952, 53-81).

None of these men had much formal training in economics, and all were outside the mainstream of professional economics then developing in the United States. They were professors of agriculture in land-grant colleges at a time when the individuals holding such professorships were expected to cover agriculture in its entirety, from chemistry to biology to farm management (Taylor 1952, 80). They ventured into the strange ground of agricultural economics because they were perceptive enough to see that the business aspects of farming were at least as important as the science of production. They were pragmatists and empiricists, not theoreticians. They understood that scientific agricultural economics required incorporation of economic principles, but they were also interested in economic geography, sociology, and accounting, and they insisted that all these subjects be mixed with generous helpings of agronomy and animal husbandry. In its earliest beginnings, therefore, agricultural economics was not seen so much as a subdiscipline of economics as a subject matter field requiring a multidisciplinary approach.

These beginnings set the direction of agricultural economics for at least 50 years. Attention was focused upon basic production problems such as the choice of farm enterprises, the intensity of culture, and the size of farms. The dominant approach was empirical, and hence, until after World War II, agricultural economists were often statisticians, developing new and better ways to collect and analyze data. They were very good at it. Our basic understanding of the mathematics of the classic production function owes much to the work of Spillman and Emil Lang; Howard R. Tolley and M. J. B. Ezekiel pioneered methods for correlation analysis; and E. J. Working explained the basic identification problem in the statistical estimation of demand curves. But the characteristic work of agricultural economists during the interwar years is probably best represented by the farm management surveys of George Warren and his colleagues at Cornell. Their 
work was aimed at gathering empirical information on farm management practices, which was largely devoid of theoretical content but which laid the foundation for modern sampling survey techniques (Taylor 1952, 358-76).

The closest that pre-World War II agricultural economists ventured toward the subject matter that now characterizes regional science was in a series of land tenure and taxation studies surveys. The preeminent scholar undertaking such work was Lewis C. Gray, an early agricultural economist/historian who headed the Division of Land Economics in the United States Department of Agriculture. The division identified five research areas: 1) land resources classification and utilization, 2) land values, 3) land ownership and tenancy, 4) land settlement, and 5) land policies (Martin 1981, 400). Many agricultural economists working in this area traced their intellectual genealogy to Ely and Commons and were strongly institutionalist in their orientations. But their methodological approach was fundamentally the same as Warren's: they did empirical surveys.

It was not until after World War II that agricultural economists began to see their subject field as a branch of economics. As far back as the turn of the century, Harvard had supported a faculty member in economics with an interest in agriculture. Thomas Nixon Carver and later John D. Black provided mentoring for agricultural economists interested in becoming first-rate economists. The University of Chicago also cultivated work in agricultural economics, first under Richard Ely and later under T. W. Schultz. The graduate program in economics at the University of Virginia also welcomed students interested in agricultural economics. Gradually, intellectually gifted graduate students interested in agricultural economics and trained rigorously in economic theory began to issue forth from these institutions and join faculties of agricultural economics in the landgrant universities. By 1950, their influence was being felt in ways that changed agricultural economics dramatically. The emphasis upon technique continued, but pure empiricism was jettisoned. The historical/geographic analysis that had long been accepted was also abandoned. A theoretical model rooted in neoclassical economics became de rigueur for publication in the leading agricultural economics journals.

From time to time, the old interests of the land economists flare up in contemporary agricultural economics. The impacts of economic change on rural America have not gone unnoticed by agricultural economists. Widespread poverty in rural areas was identified early on as a problem of underemployed labor, and in the 1950s and 1960s, the mainstream of agricultural economics focused upon rural poverty. There is currently a renewed interest in the problems of rural communities during a time when the long-term trend in real commodity prices is downward. But the lack of rigorous theoretical models of rural development has caused some agricultural economists to dismiss rural development research as 
case studies that are only a step more sophisticated in their basic methodology than the land tenure surveys of the 1920s and 1930s. Rural development has not attracted the massed econometric assault that agricultural economists feel they must bring to a public policy problem.

\section{CONTEMPORARY AGRICULTURAL ECONOMICS}

Currently, at the end of the twentieth century, the mainstream of American agricultural economics is strongly disciplinary. It is economics, albeit applied economics, and proudly (some would say, arrogantly) so. Yet the focus of the subject remains largely upon production economics and upon agriculture as an industry and as an economic sector. In the late 1970s, agricultural economists discovered macroeconomics, and a growing body of work has emerged wherein the impacts of macro policies upon agriculture are examined. Even though some of the founders of agricultural economics called their pioneering work "rural economics," the rural setting in which agricultural production takes place has received only passing and occasional attention. The area where regional science has its greatest potential to influence agricultural economics has been in recent time relegated to the periphery of the agricultural economics profession.

No one knows for sure, since the census does not count persons by the fields in which they took degrees, but the best guess is that there are more than 5,000 persons in the United States who hold one or more graduate degrees in agricultural economics and who thus might be called scientific agricultural economists. Many of them work in administrative positions in government or are in private business. About 2,500 persons regularly pay dues to the American Agricultural Economic Association, the institutional body of agricultural economists, and they can be considered the bulk of the agricultural economists engaged in some form of scholarship. The 1991 AAEA membership directory identifies about 200 of its members as specializing in some subject related to rural development, and it is this remnant of 200 that represents the constituency for regional science within agricultural economics. If regional science has had any influence upon agricultural economics, it is most likely to be evident within this subset of agricultural economists, but it should be noted that this constituency within agricultural economics represents less than 10 percent of the membership in the organized profession.

There is evidence, however, that within this small constituency, the influence of regional science is considerable. Of the approximately 600 persons who regularly pay dues to the Southern Regional Science Association, about 100 are employed by organizations doing agricultural economics. That means that about 
half of all agricultural economists in the United States who specialize in rural development belong to the Southern Regional Science Association. Others likely belong to regional science organizations centered in other parts of the country. It seems reasonable to conclude that a majority of all agricultural economists involved in rural development scholarship are active in some way in organized regional science and subject to the influence of regional science.

How did this influence come about, and what have been its effects?

\section{REGIONAL SCIENCE AND RURAL DEVELOPMENT}

The question posed above cannot be answered definitively without wideranging research that is well beyond the scope of this paper. Absent such research, perhaps the best one can do is speculate about why regional science has captured such a large proportion of rural development specialists in agricultural economics. Timing appears to have been a critical factor. The interest of agricultural economists in rural problems in the 1950s and 1960s coincided with the birth of regional science. Agricultural economists, looking around at new additions to the literature for inclusion on graduate reading lists, could not have helped but notice the (then) recent work of Isard. That work, being new and presumably up-to-date, meant that many of the agricultural economists trained in rural development in the 1950s and 1960s cut their teeth on Location and Space Economy and on Methods of Regional Analysis. From Isard, it was a short intellectual trip to the influential work of Friedman and Alonso and to Miemyk's Elements of Input-Output Analysis: Thus, the generation of agricultural economists/rural development specialists that is now reaching maturity in land-grant colleges of agriculture were introduced to some of the seminal works in regional science during their graduate studies and were thereby drawn into regional science circles.

In numbers, these agricultural economists/rural development specialists were few-not more than a handful really. But they propagated regional science concepts among their own graduate students during the 1970s and 1980s, and increasingly their students followed them to regional science meetings, first as junior co-authors of papers, then later as senior authors. Over a generation, the numbers multiplied, and regional science meetings, as well as regional science journals, now regularly and routinely include the work of agricultural economists.

Organized regional science has been especially important to agricultural economists/rural development specialists because it has given them an intellectual home during a time when their speciality did not much interest the bulk of agricultural economists. Forced to the margins of their own professional organizations, these agricultural economists discovered that regional science offered intel- 
lectual nourishment through interaction with other scholars sharing a common interest and opportunities to publish. There are agricultural economists who owe their tenure and promotion within the academic community to this nourishment and to these publication opportunities. It is probable that some agricultural economists would have continued their interest in regional matters during the 1970s and 1980s if regional science had not offered such a home, but they might well have been an insular, isolated remnant rather that the vigorous group that they are.

The influence of regional science is most clearly evident in the work of agricultural economists who use input-output models. Nothing has been more characteristic of regional science work during the past 20 years than the development of refined techniques for building regional input-output matrices. Despite all the controversy over the validity of synthesized regional models, pragmatic agricultural economists understood that if input-output models were to have much practical usefulness, it was necessary that ways be found to avoid the costs of building models from primary data. Hence, they were greatly interested in the work of Schaffer, Stevens, and Jensen, which offered possibilities for shortcuts in building such models. That work, refined and synthesized by Alward and a team at the U.S. Forest Service, led to the development of the IMPLAN procedure. And no new technique of analysis has had greater impact on the practice of agricultural economics during the past decade than IMPLAN (see Johnson and Swallow 1987).

Another influence upon agricultural economics coming, at least in part, from the interaction between agricultural economists and geographers within regional science organizations can be seen in the growing work on geographic information systems (GIS) being published by agricultural economists. Within the past five years, agricultural economists have discovered the possibilities for a new level of applied regional analysis using the data bases of GIS (see Henry 1991). As more and more graduate students in agricultural economics develop familiarity with the computer architecture of GIS, that work can be expected to explode and to force agricultural economists to borrow some more from regional science, particularly from the work on the areal statistics of regional scientists like Getis and Boot and Rogers.

But whenever two groups come together, influence usually runs in both directions. Regional science is almost certain to be influenced by the involvement of agricultural economists. Two examples of the influence of agricultural economics upon regional science seem to be developing: agricultural economists have brought to regional science a renewed interest in human capital as a factor in the performance of regional systems, and they are prodding regional scientists to 
consider how their scholarship might best be made available to practitioners. Both of these new influences are sufficiently important to deserve further comment.

It would be incorrect to say that regional scientists took no notice of human capital before agricultural economists began to present papers at the meetings dealing with the subject. But it seems fair to say that before 1970, regional scientists did not differentiate between human and physical capital in most of their models. The Schultz influence in agricultural economics has caused human capital to be on the minds of most agricultural economists for more than a generation. Agricultural economists such as McNamara and Smith have caught the attention of regional scientists with their work that attempts to determine the ways differences in human capital endowments affect regional economies. The case for considering human capital is so persuasive that it seems likely that regional scientists will give the matter considerable attention in the years immediately ahead.

The second impact of agricultural economics upon regional science results from the extension responsibilities of many rural development specialists. David Barkley of Clemson, Gerald Doeksen of Oklahoma State, Tom Johnson and George McDowell of VPI and SU, David Kraybil of Ohio State, Warren Kriesel of the University of Georgia, and Glen Pulver and Ron Shaffer ${ }^{1}$ of the University of Wisconsin have brought to regional science not only their considerable abilities as scholars and analysts, but also their special concerns as extension specialists in making the subject matter relevant to practitioners. They are organizing sessions on the problem at regional science meetings and are drawing impressive attendance. The results are that regional scientists are being forced to consider in new ways Rutledge Vining's injunction to make sure that the subject of the science is the subject of its practice.

Agricultural economists/rural development specialists continue to have needs that regional science may be able to satisfy. One of the most important of those needs is for a theory of rural development that is compatible with the neoclassical economic paradigm. In short, the need is for a reductionist theory of economic activities in space. Impressive, valiant efforts by Isard (1969) and Faden have failed to produce such a theory, at least in a satisfactory, usable form, and it may be that no such theory is possible. But the need is so strong that agricultural economists are likely to continue coming to regional science in search of theory, and even if the theory is not forthcoming, the insights and methods of regional science will creep into agricultural economics just as the special concerns of agricultural economists will modify regional science.

Yet it would be wrong to leave the impression that regional science has radically altered the way agricultural economists/rural development specialists see the world. Only recently, on the occasion of its 75th anniversary, the American Agricultural Economic Association sponsored a symposium that reviewed various 
fields of scholarly interest to members of the profession. Deaton and Weber prepared the review of "The Economics of Rural Areas" (in Hildreth et al. 1988, 403-439). In the more than three pages of references cited in this paper, one finds authors familiar to regional scientists-Edgar Dunn, Irving Hoch, J. Tinbergen, and J. G. Williamson, for example. But one looks in vain for any citation to regional science literature. The disciplinary pull of economics is evident, but the paper could have been written even if regional science had never come on the scene. Even among that small band of agricultural economists who specialized in rural development, regional science has only begun to exert important influence.

\section{CONCLUSION}

The task undertaken in writing this paper was an assessment of the influence of regional science upon agricultural economics. The approach I have used draws both upon the written record of the literature of the two fields of study and upon observations during a 25-year career in which I have found it useful to keep one foot in each discipline. It is a subjective assessment, colored by my own perspective, and undoubtedly incomplete. But few agricultural economists or regional scientists would probably disagree with the following broad conclusions:

1. The influence of regional science upon agricultural economics has been confined to only a relatively small subset of agricultural economists interested in rural development.

2. The interest in regional science of these agricultural economists/rural development specialists has increased considerably in the 1970s and 1980 s, and agricultural economists are now at least as numerous as geographers as participants in organized regional science activities.

3. The most pronounced influence of regional science upon agricultural economics has had to do with the development and use of synthesized regional input-output models.

4. Increased participation in regional science activities by agricultural economists with extension orientations is causing regional scientists to focus upon making their scholarship relevant to the needs of practitioners.

\section{ENDNOTES}

1. A good illustration of how agricultural economists active in regional science have synthesized the two fields can be found in Shaffer's textbook. 


\section{REFERENCES}

Alward, G., E. Siverts, D. Olson, J Wagner, D. Senf, and S. Lindall. Micro IMPLAN Software Manual. Minneapolis: University of Minnesota Press, 1989.

Ezekiel, M. J. B. "A Method for Handling Curvilinear Correlation for Any Number of Variables." Journal of the American Statistical Association 19 (December 1924): 431-53.

Faden, A. M. Economics of Space and Time. Ames: Iowa State University Press, 1977.

Freidman J., and W. Alonso, eds. Regional Development and Planning. Cambridge: MIT Press, 1964.

Getis, A., and B. Boots. Models of Spatial Processes. London: Cambridge University Press, 1978.

Henry, M. S. "Modelling Regional Economic Change with the Aid of Geographic Information Systems: Authentic Regional Science?" Review of Regional Studies 21 (Summer 1991): 107-118.

Hildreth, R. J., K. L. Lipton, K. C. Clayton, and C. C. O'Connor, eds. Agriculture and Rural Areas Approaching the Twenty-first Century. Ames: Iowa State University Press, 1988.

Isard, W. Location and Space Economy. Cambridge: MIT Press, 1956. Methods of Regional Analysis. Cambridge: MIT Press, 1960. - General Theory-Social, Political, Economic and Regional. Cambridge: MIT Press, 1969.

Johnson, T., and B. Swallow. "A Fiscal Impact Model for Virginia Counties." Review of Regional Studies 17 (Spring 1987): 67-74.

Martin, L. R., ed. A Survey of Agricultural Economics Literature. Minneapolis: University of Minnesota Press, 1981.

McNamara, K. T., W. P. Kriesel, and B. J. Deaton. "Manufacturing Location: The Impact of Human Capital Stocks and Flows." Review of Regional Studies 18 (Winter 1988): 42-28.

Mynierk, W. H. Elements of Input-Output Analysis. New York: Random House, 1965.

Rogers, A. Statistical Analysis of Spatial Distributions. London: Pion, 1974.

Shaffer, R. Community Economics. Ames: Iowa State University Press, 1989.

Smith, E. D. Reflections on Human Resources in the Strategy of Rural Development 19 (Winter 1989): 13-22.

Spillman, W. J., and E. Lang. The Law of Diminishing Returns. Yonkerson-Hudson, N.Y.: World Book Co., 1924. 
Taylor, Henry C., and Anne Dewees. The Story of Agricultural Economics in the United States, 1840-1932. Ames: Iowa State College Press, 1952.

Tolley, H. R., and M. J. B. Ezekiel. "A Method for Handling Multiple Correlation Problems." Journal of the American Statistical Association 18 (December 1923): 993-1003.

Vining, R. "Seeing to It that the Subject of the Science Is the Subject of Its Practice: Toward a Theory of the Outcome of an Economic System's Working." Review of Regional Studies 18 (Winter 1988): 1-3.

Working, E. J. "What Do Statistical Demand Curves Show?" Quarterly Journal of Economics 41 (February 1927): 212-235. 